\title{
Benchmarking the Oxygen Reduction Reaction Activity of Pt-based Catalysts Using Standardized Rotating Disk Electrode Methods
}

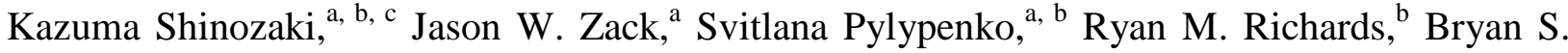 \\ Pivovar $^{a}$ and Shyam S. Kocha ${ }^{a}$ \\ ${ }^{a}$ National Renewable Energy Laboratory, Electrochemical Characterization Labs, Golden, CO 80401, USA \\ ${ }^{b}$ Colorado School of Mines - Department of Chemistry, Golden, CO 80401, USA \\ ${ }^{c}$ Toyota Central R\&D Labs., Inc., Aichi, 480-1192 Japan \\ Shinozaki@mosk.tytlabs.co.jp \\ shyam.kocha@nrel.gov+1-303-275-3284
}

\begin{abstract}
Thin-film rotating disk electrodes (TF-RDEs) have become the preferred half-cell technique for screening small lab-scale quantities of electrocatalysts targeted for proton exchange membrane fuel cells. Utilizing standardized protocols and best practices for Nafion-based catalyst layer fabrication, we demonstrate that catalyst layers fabricated with the rotational air drying technique result in improved film quality and $\sim 1.6 x$ higher ORR activity as compared to the conventional stationary air drying technique for $\mathrm{PtCo} / \mathrm{C}$ catalysts. The ORR activity of a series of candidate Pt-based electrocatalysts having improved kinetics (Pt-alloys), corrosion-resistance carbon supports, various $\mathrm{Pt} w \mathrm{t} \%$ and the implications for practical proton exchange membrane fuel cells (PEMFCs) is discussed.
\end{abstract}

\section{Keywords}

Fuel Cell; RDE; ORR; Platinum; Catalyst 


\section{Introduction}

With the imminent commercialization of automotive PEMFCs, research has accelerated on the residual issues of electrocatalyst cost in labs worldwide. In order to meet the cost target $(\$ 30 / \mathrm{kW})$, a factor of $\mathrm{x} 4$ reduction of Pt content to $10 \mathrm{~g} / 100 \mathrm{~kW}$-stack is necessary. The target can be achieved by developing novel catalysts that have a $\mathrm{x} 4$ enhancement in ORR activity over the current status. Universities and laboratories typically synthesize extremely small quantities of novel high activity candidate electrocatalysts not suitable for evaluation in a fuel cell. A rapid screening half-cell technique that produces reliable values is indispensable for evaluation of these materials prior to scale-up. Half-cell techniques have been employed to measure the ORR specific activity (SA) and mass activity (MA) of nanoparticles catalysts and used as a predictor of the activity in actual fuel cells for the last 50 years. We take a brief look at the various halfcell techniques that are available for evaluation of PEMFC catalysts and point out their advantages and disadvantages versus the RDE technique that has, of recent, become the technique of choice.

The floating electrode technique was originally applied to study the kinetics of ORR and mass transport in PAFCs between the 1960's and 1980's. ${ }^{1-13}$ In these initial studies, PTFE bonded catalyst layers $(\sim 200 \mu \mathrm{m})$ were coated on a gas diffusion layer (GDL); the electrode was positioned so that it was in contact with the acid electrolyte but not immersed and flooded. ${ }^{4}$ Some of the pores in the catalyst layer and GDL functioned as gas phase $\mathrm{O}_{2}$ transport pathways due to the hydrophobic nature of PTFE; due to hydrophilicity of the catalyst interface with the electrolyte, proton transport pathways are also present. Since $\mathrm{O}_{2}$ transport takes place predominantly through the gas phase, $\mathrm{O}_{2}$ diffusion-limited currents are typically large in these systems and this method has been successfully used to screen novel electrocatalyst for PAFCs and reasonably high values of activity have been obtained. The activity trend of Pt-based catalysts measured by the floating electrode method $^{9}$ is comparable to that reported by other techniques, ${ }^{14-19}$ and to that in actual fuel cells. However, the technique suffers from a few drawbacks related to the thickness of the catalyst layer: i) $\mathrm{O}_{2}$ transport to some catalyst sites that are far from the gas pores is slow; ${ }^{2,3,12}$ ii) the $i R$ loss within the catalyst layer can be significant and is anticipated to affect the ORR activity measurement supported by studies of $\sim 10 \mu \mathrm{m}$ thick layers on MEAs; ${ }^{20-23}$ iii) the method requires relatively large amount of catalyst $(\sim 1 \mathrm{~g})$ to fabricate the electrodes.

The floating electrode method originally used with PTFE bonded electrodes for PAFCs has recently been adapted for PEMFC studies. ${ }^{24-26}$ Antolini et al. ${ }^{24}$ studied the effect of Nafion content on the ORR performance of catalyst layers; the catalyst layers fabricated in this work, however, were $40 \mu \mathrm{m}$ in thickness with a loading of $200 \mu \mathrm{g}_{\mathrm{Pt}} / \mathrm{cm}^{2}$, and suffered from mass transfer limitations and thus resulted in inaccuracies in the ORR measurements. Later, Chen et al. $^{25}$ fabricated Pt film ( $3 \mathrm{~nm}$ thick) deposited on a carbon cloth supported on a porous PTFE membrane substrate in an attempt to minimize the $\mathrm{O}_{2}$ transport limitation by the thin electrolyte film on catalyst surfaces. The electrode is sandwiched between two cell components so that one side of the electrode is in contact with electrolyte solution and the other side of the electrode is directly connected to the gas phase. They demonstrated that with their configuration kinetic currents could be obtained over a wide potential range (0.6-0.9 V vs. RHE). Most recently, Zalitis et al. ${ }^{26}$ have reported the use of thin Pt/C catalyst layers $\left(0.16 \mu \mathrm{g}_{\mathrm{Pt}} / \mathrm{cm}^{2}\right.$ to $2.5 \mu \mathrm{g}_{\mathrm{Pt}} / \mathrm{cm}^{2}$, where $0.16 \mu \mathrm{g}_{\mathrm{Pt}} / \mathrm{cm}^{2}$ in $200 \mathrm{~nm}$ in thickness) to apply the learnings from Chen et al. ${ }^{25}$ for $\mathrm{Pt} / \mathrm{C}$ catalysts. In order to obtain a thin film, catalysts were deposited on the substrate material by 
vacuum filtration of a catalyst ink (Pt/C catalyst, Nafion and organic solvents). The substrate was a Teflon coated porous polycarbonate track etched (PCTE) membrane with Au sputtered on one side; $\mathrm{Au}$ functions as electron collector and hydrophobic pores provide gas phase $\mathrm{O}_{2}$ transport pathways. Large $\mathrm{O}_{2}$ diffusion limiting currents were achievable using this method compared to the maximum limiting current obtained by the RDE method. Hence, kinetic currents could be obtained at potential range greater than $\sim 0.6 \mathrm{~V}$ vs. RHE. The SA for a Pt/C catalyst measured using this method is comparable to the literature values measured using conventional TF-RDE method, ${ }^{18,27-30}$ but is only half of that measured using advanced TF-RDE methods. ${ }^{19,27,29-33}$ This could partially stem from the difference in perchloric acid concentration used as the electrolyte solution (4.0 $\mathrm{M}$ in this method and $0.1 \mathrm{M}$ in the literature reporting the higher $\mathrm{SA}^{29-31}$ ) as higher concentrations of acids are known to lower the measured activity due to increased anion poisoning. ${ }^{34-37}$ Another shortcoming of this method is that the Pt loading cannot be accurately controlled because the pore size of the PCTE membrane is so large that some catalyst agglomerates can pass through the membrane. With ongoing refinements, the floating electrode technique can become a powerful alternative for the study of ORR kinetics in the future.

In 2008, Kucernak et al. ${ }^{38}$ proposed a gas phase wall-jet electrode method in an attempt to fabricate a PEMFC-like system that achieves large $\mathrm{O}_{2}$ diffusion limiting current and requires only small amount of catalysts (10's of mg). In this method, a catalyst and Nafion ionomer is deposited on a $\mathrm{Au}$ grid $\left(\sim 10 \mu \mathrm{g}_{\mathrm{P}} / \mathrm{cm}^{2}\right)$ and pressed onto a Nafion membrane using a glass tube with Au coating. This structure allows the catalyst to connect protonically to the membrane and electronically to the current collector $(\mathrm{Au})$. A Pt counter electrode is in contact with the membrane on the other side, and an RHE is attached on the membrane to control potential of the working electrode. Gases introduced from the needle placed in the glass tube impinge the catalyst and allow fast $\mathrm{O}_{2}$ transport. They demonstrated a large limiting current allowing a kinetic current to be measured over a wide potential range. However, the $\mathrm{SA}$ for $\mathrm{Pt} / \mathrm{C}$ catalyst (80 $\mu \mathrm{A} / \mathrm{cm}_{\mathrm{Pt}}^{2}$ ) is lower than that reported in the literature based on conventional TF-RDE techniques and FC testing $\left(\sim 250 \mu \mathrm{A} / \mathrm{cm}^{2}{ }_{\mathrm{Pt}}\right.$ and $\sim 200 \mu \mathrm{A} / \mathrm{cm}^{2}{ }_{\mathrm{Pt}}$, respectively $\left.{ }^{18}\right)$. A possible cause of the lower measured activity could be attributed to the fact that the wires of the Au grid are fairly wide and $\mathrm{O}_{2}$ cannot diffuse quickly to the catalyst deposited near the central region of the wire. The principal advantage of the method is that the ORR activity can be measured in a similar environment to the FC with very small catalyst quantities at high temperature and low $\mathrm{RH}$ conditions. However, the catalyst loading cannot be easily controlled as it needs to be deposited on very thin wire substrate. Although a FC-like system with small amounts of catalysts is highly attractive, further refinements are necessary before this technique becomes main-stream.

Channel Flow Dual Electrode (CFDE) and RDE (including other rotational techniques) are generally categorized under hydrodynamic electrode methods. These methods utilize laminar flow parallel to the surface of the electrode to achieve controlled mass transport for the entire electrode surface area. ${ }^{39,40}$ The main difference between the two hydrodynamic methods (flow and rotational type) is the strategy involved in establishing laminar flow at the electrode surface. The primary advantage of these techniques is that a kinetic current can be easily extracted by applying the well-known Koutecky-Levich (K-L) equation (Eq. 1) for well-defined $\mathrm{O}_{2}$ diffusion limiting currents.

$$
\frac{1}{i}=\frac{1}{i_{\mathrm{k}}}+\frac{1}{i_{\lim }}
$$


where $i$ is the raw current, $i_{\mathrm{k}}$ is the kinetic current, $i_{\text {lim }}$ is the $\mathrm{O}_{2}$ diffusion limiting current. ${ }^{40} \mathrm{~A}$ disadvantage of this technique is that the potential range from which kinetic information for the ORR can be obtained is narrow (>0.7-0.8 V vs. RHE).

Gerischer et al. ${ }^{39}$ originally presented the CFDE method in 1965. Subsequently, Itagaki et al. $^{41}$ applied this method to study the ORR mechanism on smooth bulk electrodes in an aqueous alkaline solution for the first time in 2003 . Wakabayashi et al. ${ }^{42,43}$ advanced the technique by using the CFDE to study temperature dependence on the ORR kinetics for bulk Pt alloy materials as well as high surface area catalysts such as $\mathrm{Pt} / \mathrm{C}$ by forming a thin-film catalyst layer on a bulk substrate such as a glassy carbon (GC) substrate (TF-CFDE). ${ }^{44}$ A typical experimental configuration of the CFDE method includes the working electrode, the collector electrode, the reference electrode placed in between the collector electrode and the counter electrode. By applying a high potential such as $1.2 \mathrm{~V}$ vs. RHE, $\mathrm{H}_{2} \mathrm{O}_{2}\left(2 \mathrm{e}^{-}\right.$reduction reaction product in the ORR) released from the working electrode can be detected at the collector electrode. In addition, the set-up is functional up to $\sim 90^{\circ} \mathrm{C}$ without solution evaporation so that high temperature studies are possible. ${ }^{42-44} \mathrm{~A}$ drawback of the CFDE method is the system complexity including long tubes that are difficult to clean than alternative set-ups; the effect of contamination is reflected in the significantly lower activity values than that obtained using RDE techniques. ${ }^{43,45}$

Since the original work of Gloaguen et al. ${ }^{46}$ who introduced the TF-RDE method, refinement/modification of the catalyst layer fabrication technique and measurement protocols have been ongoing for the last two decades. ${ }^{17,19,27,28,30,31,33,47-52}$ In the TF-RDE method, the catalyst is mixed with solvent and Nafion and dispersed to form an ink that is deposited on a GC electrode tip and dried to form a catalyst layer. TF-RDE techniques have several advantages including: (i) high throughput, (ii) extremely small amounts of catalysts, and, (iii) commercial availability that has led to its widespread popularity. Schmidt et al. ${ }^{47}$ advanced the technique by introducing Nafion ionomer in the form of a 'cap' over the $\mathrm{Pt} / \mathrm{C}$ electrode to obtain stable catalyst films with simplified catalyst layer structure. Paulus et al. ${ }^{49}$ studied the effect of Nafion cap film thickness on the ORR using the catalyst layer fabrication technique reported by Schmidt et al. ${ }^{47}$ and concluded that $1 / i_{\mathrm{f}}$ term in the extended K-L equation (Eq. 2) becomes negligible for the film thickness $<0.2 \mu \mathrm{m}$.

$$
\frac{1}{i}=\frac{1}{i_{\mathrm{k}}}+\frac{1}{i_{\mathrm{d}}}+\frac{1}{i_{\mathrm{f}}}
$$

where $i_{\mathrm{d}}$ is the $\mathrm{O}_{2}$ diffusion limiting current through the bulk eletrolyte and $i_{\mathrm{f}}$ is the $\mathrm{O}_{2}$ diffusion limiting current through the ionomer film (when $1 / i_{\mathrm{f}}=0,1 / i_{\mathrm{lim}}=1 / i_{\mathrm{d}}$ ). ${ }^{53}$ Higuchi et al. ${ }^{54}$ employed a controlled ink drying process that allows an uniformly dispersed ultra-thin catalyst layer, and re-evaluated the effect of Nafion cap thickness on the ORR activity measurement (TFCFDE). They concluded that for the Nafion film thickness $<0.1 \mu \mathrm{m} 1 / i_{\mathrm{f}}$ term becomes negligible.

Takahashi et al. ${ }^{28}$ were among the first to investigate the impact of catalyst ink formulation on the ECA and ORR activity by varying the proportion of water to IPA, as well as sonication time; they reported $\sim 20 \%$ ECA increase with optimized ink formulations. They reliably determined average values (10 samples) of ECA, SA and MA for $46 \mathrm{wt} \% \mathrm{TKK} \mathrm{Pt} / \mathrm{HSC}$ of $91 \mathrm{~m}^{2} / \mathrm{g}_{\mathrm{Pt}}, 292 \mu \mathrm{A} / \mathrm{cm}^{2}{ }_{\mathrm{Pt}}$ and $266 \mathrm{~mA} / \mathrm{mg}_{\mathrm{Pt}}$ at $0.9 \mathrm{~V}, 25^{\circ} \mathrm{C}, 100 \mathrm{kPa}, 10 \mathrm{mV} / \mathrm{s}$ in $0.1 \mathrm{M} \mathrm{HClO}_{4}$. However, the measured ORR activity has been found to be a function of the applied measurement protocol, ink formulation and dispersion as well as the resulting film quality; a prerequisite is the impurity level in the electrochemical system that can be estimated based on the ORR activity of a poly-Pt disk. Pollet et al. ${ }^{51}$ studied the effect of sonication (frequency, 
power, duration to disperse Pt/C catalyst inks) on the ECA. They found sonication power of $\sim 2-$ $3 \mathrm{~W}$ for $<30 \mathrm{~min}$ resulted in the highest ECA and reported the ECA of $\sim 100 \mathrm{~m}^{2} / \mathrm{g}_{\mathrm{Pt}}$ for $46 \mathrm{wt} \%$ TKK Pt/HSC in $0.1 \mathrm{M} \mathrm{HClO}_{4}$. They also demonstrated that sonication at higher powers quickly increased the ink temperature and a longer sonication resulted in deleterious effect on the ECA. Garsany et al. ${ }^{29,31,50}$ in a series of papers incrementally improved the quality of RDE films to obtain reproducible results; they introduced for the first time a rotational drying technique to reduce the 'coffee ring effect' that resulted in a thick band of catalyst being deposited at the periphery of the electrode. They reported $\mathrm{x} \sim 1.7$ higher measured SA using their rotational drying technique compared to that obtained with the catalyst layers fabricated using conventional stationary drying technique. Ke et al. ${ }^{30}$ reported higher SAs $(x 1.6)$ for films $(<1 \mu \mathrm{m})$ fabricated with a novel, proprietary automated ink-dispensing device capable of depositing thousands of 'nanoliter sized droplets' onto the GC compared to SAs obtained with the catalyst layers fabricated using conventional stationary drying technique. Nesselberger et al. ${ }^{19}$ and van der Vliet et al. $^{52}$ elucidated the importance of $i R$ and background current corrections that is only sporadically applied by researchers to obtain the ORR activities. Most recently, Kocha et al. ${ }^{27}$ and Shinozaki et al. ${ }^{33,55}$ carried out investigations on the effect of ionomer in the RDE catalyst layer and fabrication techniques and also established standardized ORR measurement protocols in collaboration with other laboratories. ${ }^{56}$

In this work, we focus primarily on the rotational air drying technique which is less susceptible to user skill and produces more uniform films than the conventional stationary air drying technique. The ORR activity of a number of Pt-based electrocatalysts such as Pt-alloy/C and Pt/graphitized supports has been reported in the literature using traditional stationary air drying techniques that included unaccounted $\mathrm{O}_{2}$ diffusion losses. In the light of recent work including the development of standardized protocols and best practices, we have re-examined a series of catalysts using Nafion-based rotational air drying techniques as they are anticipated to exhibit a better measure of the ORR activity.

\section{Experimental}

\subsection{Electrocatalysts, chemicals and reactant gases.}

All catalysts employed in this study were manufactured by Tanaka Kikinzoku Kyogyo (TKK, Japan) and the detailed specifications along with the nomenclature for the various catalysts are listed in Table 1. Surface area obtained from BET method and CO chemisorption and crystallite size from XRD were provided by the manufacturer. Deionized (DI) water (>18.2 $\mathrm{M} \Omega \cdot \mathrm{cm}$, TOC $<5 \mathrm{ppb}$ ) from a Milli Q system (Millipore) was used in acid dilutions and glassware cleaning. The following chemicals were used in electrolyte preparation and ink formulation: Isopropanol (IPA, CHROMASOLV ${ }^{\circledR}$ Plus, for HPLC, 99.9\%, Sigma-Aldrich), Nafion solution (DE520, EW1000, $5 \mathrm{wt} \%, 0.924 \mathrm{~g} / \mathrm{mL}$, Sigma-Aldrich), $0.05 \mu \mathrm{m}$ alumina dispersion (Buehler Inc.), concentrated (conc.) sulfuric acid (Certified ACS Plus, Fisher Scientific), Nochromix ${ }^{\circledR}$ (Godax Laboratories, Inc.), and $70 \%$ perchloric acids sourced from: Veritas ${ }^{\circledR}$ Doubly Distilled (GFS chemicals) and Superior ACS (GFS chemicals) were diluted to prepare electrolytes in this work. Measured amounts of $70 \% \mathrm{HClO}_{4}$ were poured directly from the original acid container into clean PFA or FEP bottles and diluted to prepare $\mathrm{HClO}_{4}$ solutions. All electrochemical measurements were carried out in $0.1 \mathrm{M} \mathrm{HClO}_{4}$ aqueous solution prepared 
from $70 \% \mathrm{HClO}_{4}$ and DI water. Gases used in this study were classified as ultrapure grade $\left(\mathrm{N}_{2}\right.$, 99.9999\%, $\mathrm{H}_{2}, 99.999 \%, \mathrm{O}_{2}, 99.9999 \%, \mathrm{CO} 99.998 \%$ Matheson Gas).

Table 1. Electrocatalyst specifications.

\begin{tabular}{|c|c|c|c|c|c|c|}
\hline $\begin{array}{c}\text { Metal } \\
\text { Content } \\
(w t \%)\end{array}$ & Carbon & $\begin{array}{l}\text { Nomenclature } \\
\text { for This Work }\end{array}$ & $\begin{array}{c}\text { Supplier } \\
\text { Nomenclature }\end{array}$ & $\begin{array}{c}\text { Surface Area } \\
\text { BET } \\
\left(\mathrm{m}^{2} / \mathrm{g}_{\mathrm{cat}}\right)\end{array}$ & $\begin{array}{c}\text { Surface Area } \\
\text { Co } \\
\left(\mathrm{m}^{2} / \mathrm{g}_{\mathrm{p}}\right)\end{array}$ & $\begin{array}{l}\text { Crystallite } \\
\text { Size } \\
\text { XRD (nm) }\end{array}$ \\
\hline $26.1 \mathrm{Pt}$ & $\mathrm{HSC}$ & $\mathrm{Pt} / \mathrm{HSC}$ & NA & 577.3 & 271 & 1.8 \\
\hline $46.4 \mathrm{Pt}$ & HSC & $\mathrm{Pt} / \mathrm{HSC}$ & TEC10E50E & 316.1 & 132.6 & 2.6 \\
\hline $67 \mathrm{Pt}$ & HSC & $\mathrm{Pt} / \mathrm{HSC}$ & TEC10E70TPM & 239.4 & 131.9 & 3.1 \\
\hline $46 \mathrm{Pt}$ & $\begin{array}{c}\text { Graphitized } \\
\text { HSC }\end{array}$ & $\mathrm{Pt} / \mathrm{G}-\mathrm{HSC}$ & TEC10EA50E & 93.2 & 65.0 & 2.5 \\
\hline $29 \mathrm{Pt}$ & Vulcan & $\mathrm{Pt} / \mathrm{V}$ & TEC10V30E & 143.7 & 157.3 & 2.5 \\
\hline $46.4 \mathrm{Pt}$ & Vulcan & $\mathrm{Pt} / \mathrm{V}$ & TEC10V50E & 97.9 & 77.6 & 2.5 \\
\hline 46.2 Pt & $\begin{array}{l}\text { Graphitized } \\
\text { Vulcan }\end{array}$ & $\mathrm{Pt} / \mathrm{G}-\mathrm{V}$ & NA & 58 & 70.7 & 2.3 \\
\hline $\begin{array}{l}\text { Pt:Co }= \\
46.4: 5.0\end{array}$ & $\mathrm{HSC}$ & $\mathrm{PtCo} / \mathrm{HSC}$ & TEC36E52 & 82 & 351 & 3.9 \\
\hline $\begin{array}{c}\mathrm{Pt}: \mathrm{Ni}= \\
46.2: 6.0\end{array}$ & $\mathrm{HSC}$ & $\mathrm{PtNi} / \mathrm{HSC}$ & NA & 349.0 & NA & 3.3 \\
\hline $\begin{array}{l}\text { Pt:Co:Mn = } \\
46.9: 3.4: 1.2\end{array}$ & $\mathrm{HSC}$ & PtCoMn/HSC & NA & 338.3 & 98.0 & NA \\
\hline
\end{tabular}

\subsection{Instrumentation.}

A microbalance (UMX2, Mettler Toredo) and ultrasonicator (FS30H, Fisher Scientific, output: $42 \mathrm{kHz}, 100 \mathrm{~W})$ were used for catalyst ink preparation. An optical microscope (AM4815ZT Dino-Lite Edge, Dino-Lite Digital Microscope) was routinely used to conduct lowresolution inspection of catalyst layers on GC. Autolab PGSTAT302N potentiostat operated with NOVA software from Metrohm was used to obtain cyclic voltammograms (CVs), ORR $I-V$ polarization curves, in-situ $i R$ correction and electrochemical impedance spectroscopy (EIS). RDE Rotators, PTFE rotator shafts glassy carbon (GC: $\phi=5 \mathrm{~mm}, 0.196 \mathrm{~cm}^{2}$, embedded in a PTFE cylinder) were obtained from Pine Instruments. A JEOL JSM-7000F Field Emission Microscope with EDAX Genesis Energy Dispersive X-Ray Spectrometer was employed to conduct SEM and EDX characterization and detailed analysis of the distribution of catalyst on GC substrates.

\subsection{Electrochemical cell set-up.}

The electrochemical cell design (130 mL; CE: Pt gauze; RE: RHE; WE: GC with catalyst layer) as well as detailed cleaning procedure are described in our previous work. ${ }^{56,57}$ In short, the cleaning procedure includes: (i) conc. $\mathrm{H}_{2} \mathrm{SO}_{4} / \mathrm{Nochromix}^{\circledR}$ soak in large containers placed in a hood, and, (ii) copious rinsing and boiling with DI water (3-6 times) with water replacement between boils. Between electrochemical experiments, the glassware and components were stored submerged under DI water. The cell was repeatedly rinsed with dilute $\mathrm{HClO}_{4}$ solution 2-3 times prior to being filled with a measured amount for experimentation. 


\subsection{Standardized electrochemical measurement protocols.}

Protocols for break-in/conditioning, CVs for electrochemical area (ECA) estimation and ORR $I-V$ curve measurements established based on our comprehensive experimental studies have been meticulously adhered to in this manuscript and we briefly present these measurement protocols (Table 2). ${ }^{55,56}$ For break-in/conditioning, potential cycling was conducted in the range $0.025-1.2 \mathrm{~V}$ at $500 \mathrm{mV} / \mathrm{s}$ for $50-100$ cycles. $\mathrm{H}_{\mathrm{UPD}}$ (adsorption) charge was obtained from the third cycle of $\mathrm{CV}$ measured in $0.025-1.0 \mathrm{~V}$ at $20 \mathrm{mV} / \mathrm{s}$ under $\mathrm{N}_{2}$ atmosphere and ECA was estimated using $210 \mu \mathrm{C} / \mathrm{cm}^{2}$ Pt. ORR $I-V$ curve was measured from -0.01 to $1.0 \mathrm{~V}$ at $20 \mathrm{mV} / \mathrm{s}$ and $1600 \mathrm{rpm}$ under $\mathrm{O}_{2}$ atmosphere. Correction for background (b.g.) currents were applied to all ORR $I-V$ curves measured with in-situ correction of solution resistance $\left(R_{\text {soln }}\right)$. All measurements were conducted at $23 \pm 2^{\circ} \mathrm{C}$. ORR kinetic currents have been corrected to $100 \mathrm{kPa} \mathrm{O}_{2}$ and Koutecký-Levich equation was applied to correct for $\mathrm{O}_{2}$ diffusion in electrolyte solution to obtain the SA $\left(\mu \mathrm{A} / \mathrm{cm}_{\mathrm{Pt}}^{2}\right)$ and MA $\left(\mathrm{mA} / \mathrm{mg}_{\mathrm{Pt}}\right)$. The SA and MA are reported at $0.9 \mathrm{~V}$ vs. RHE in this work. High frequency resistance was acquired to obtain $R_{\text {soln }}$ using an FRA (AutoLab) at $0.45 \mathrm{~V}$ under $\mathrm{N}_{2}$ atmosphere ( $2500 \mathrm{rpm}$ ) with a $5 \mathrm{mV}$ amplitude voltage perturbation.

Table 2. Schematic representation of the potential profile and detailed protocol for conditioning, ECA measurement, and ORR activity measurement of Pt based electrocatalysts in $0.1 \mathrm{M} \mathrm{HClO}_{4}$ at $100 \mathrm{kPa}$.

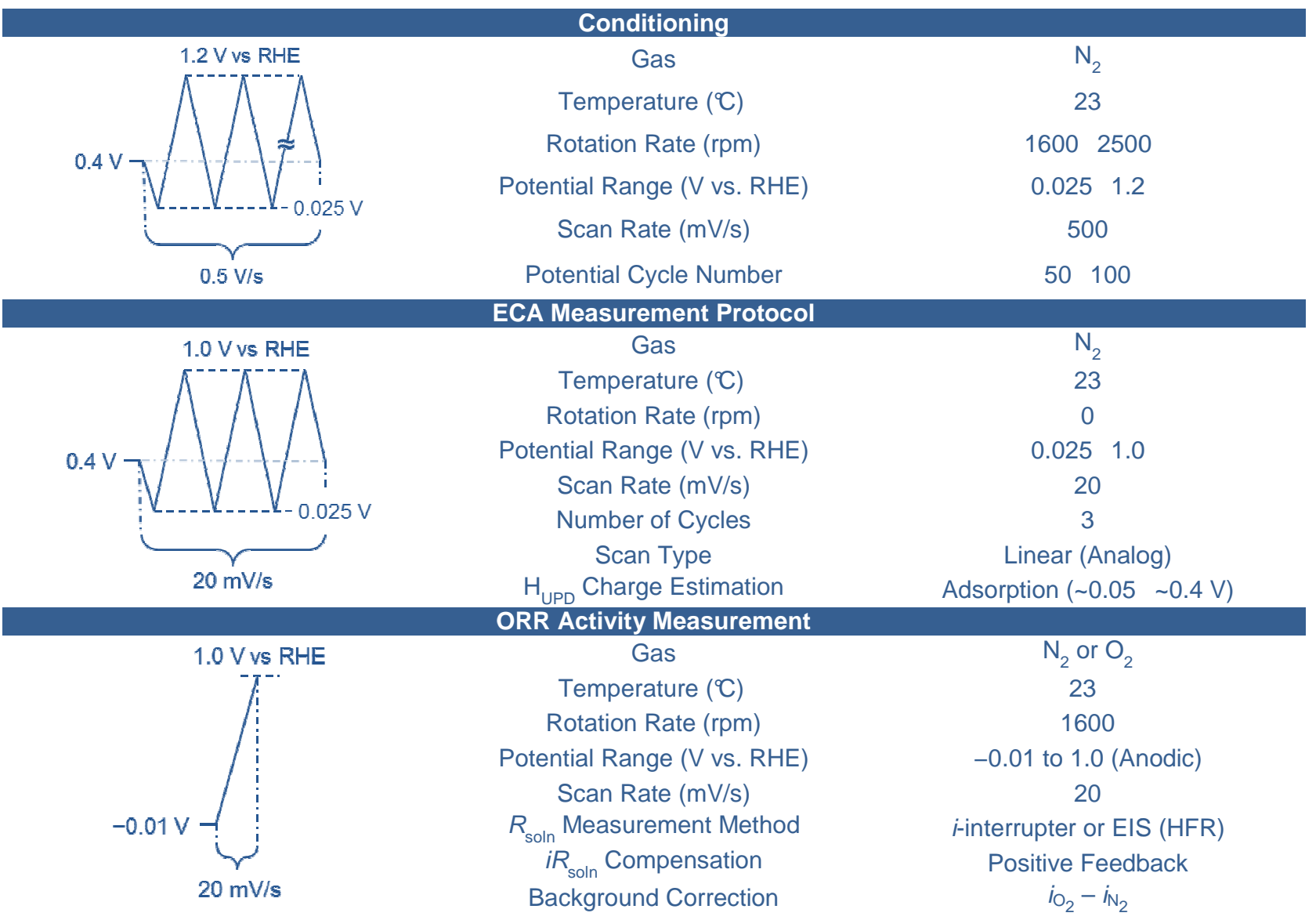




\subsection{Catalyst layer fabrication techniques.}

The GC tips were polished using $0.05 \mu \mathrm{m}$ alumina, rinsed with DI water, sonicated in DI water for $\sim 30$ seconds followed by a final DI water rinse. The tips were dried using a nitrogen gun prior to apply catalyst inks. Catalyst inks were prepared by mixing $5.3-12.1 \mathrm{mg} \mathrm{Pt} / \mathrm{C}$ or $\mathrm{PtCo} / \mathrm{C}$ catalyst powder with $7.6 \mathrm{~mL}$ DI water, $2.4 \mathrm{~mL}$ IPA, and $19-93 \mu \mathrm{L}(\mathrm{I} / \mathrm{C}=0.5)$ of $5 \mathrm{wt} \%$ Nafion solution ${ }^{27,33}$ and sonicated in an ice-water bath until catalyst ink is well-dispersed $(\sim 20$ minutes). A $10 \mu \mathrm{L}$ aliquot of the catalyst ink $\left(18 \mu \mathrm{g}_{\mathrm{P}} / \mathrm{cm}^{2}\right)$ was pipetted onto the polished GC tip mounted on an inverted rotator shaft at $100 \mathrm{rpm}$. The ink was subsequently dried under ambient conditions by increasing and maintaining the rotator speed at $700 \mathrm{rpm}$ for a period of $15 \mathrm{~min} .{ }^{29}$ We refer to this fabrication technique as 'rotational air drying' or N-RAD technique where ' $\mathrm{N}$ ' refers to Nafion incorporation. Alternatively, the conventional Nafion-based fabrication technique that involves deposition of a similar catalyst ink onto a stationary GC tip is referred to as the 'stationary air drying' or N-SAD technique.

\section{Results and Discussion}

One of the elementary ways to determine the qualitative degree of uniformity of a catalyst layer on GC is through the observation of the ORR $I-V$ profile. Fig. 1 depicts the ORR Tafel plots and $I-V$ profile (inset) for catalyst layers of identical loading $\left(18 \mu \mathrm{g}_{\mathrm{Pl}} / \mathrm{cm}^{2}, \mathrm{Pt} / \mathrm{HSC}\right)$ fabricated using the N-SAD and N-RAD techniques as well as bulk poly-Pt. It is evident that in the mixed kinetic-diffusion regime, the $I-V$ profile for layers fabricated by the N-RAD technique exhibits a sharper transition to the limiting current and exhibits lower Tafel slopes. In fact, ORR $I-V$ profiles for poly-Pt may be considered to be the limiting case for a thin film (roughness factor of $~ 1.3$ ) and exhibits the sharpest transition.

SEM images of the tilted catalyst layer on GC for Pt/HSC using the N-SAD technique (Fig. 2a, 2b) and the N-RAD technique (Fig. 2c, 2d) illustrate the variation of the thickness at the periphery (edge, yellow) and central regions (rest). Although both films show a certain degree of 'coffee ring' feature at the periphery, the width of this band is lower by $50 \%$ for the N-RAD technique. Since catalyst layers fabricated by both techniques have different degrees of uniformity, we estimate an effective thickness from thickness and the vol\% of its thickness (vol\% weighted thickness) as a measure of $\mathrm{O}_{2}$ diffusion path length. To estimate the effective thickness, catalyst layer was separated into two regions, periphery (yellow area in Fig. 2) and the rest of area. The distribution of catalyst was estimated to be $\sim 70$ vol\% on periphery and $\sim 30$ vol\% on the rest of area for catalyst layers fabricated by the N-SAD technique and $\sim 30 \mathrm{vol} \%$ periphery and $\sim 70 \mathrm{vol} \%$ on the rest of area for those fabricated by the N-RAD technique. The effective thickness was estimated to be $\sim 2.6 \mu \mathrm{m}$ for the layers fabricated by the N-SAD technique while $\sim 1.8 \mu \mathrm{m}$ for those fabricated by the N-RAD technique for identical catalyst loadings. Although our process of estimation involves some errors, the resultant porosity of the catalyst layers $(65-75 \%)$, calculated from the total volume of the catalyst layer, carbon/ionomer loading and carbon/ionomer densities $\left(2 \mathrm{~g} / \mathrm{cm}^{3}\right)$, agrees closely with that reported in literature for MEAs of PEMFCs. ${ }^{21,58}$ Figure 3 shows elemental maps that reveal (F signals) the location of Nafion ionomer to be predominantly over the coffee ring band (Pt signals) regardless of catalyst layer fabrication techniques. 
Fig. 1

Fig. 2

Fig. 3

The results for Pt/HSC discussed in Fig. 1 may also be summarized concisely as a bar chart detailing ECA, SA, MA and $i_{\text {lim }}$ (Fig. 4). The $\mathrm{O}_{2}$ diffusion limiting currents $\left(i_{\text {lim }}\right)$ are an indicator of coverage of geometric area with catalyst as long as Nafion content in catalyst layer is low enough not to affect $\mathrm{O}_{2}$ diffusion in RDE experiments. ${ }^{49,54}$ Although distribution of Nafion in catalyst layer is expected to be different from the literature ${ }^{49,54}$ and our work because of difference in Nafion incorporation process (cap vs. mixed in ink), we note that calculated Nafion thickness assuming cap form in our work $(0.02-0.1 \mu \mathrm{m})$ is below the threshold value reported in literature $(0.1-0.2 \mu \mathrm{m}) .{ }^{49,54}$ The magnitude of $i_{\text {lim }}$ for N-SAD technique $\left(5.7 \pm 0.1 \mathrm{~mA} / \mathrm{cm}^{2}\right)$ was found to be comparable to that for the N-RAD technique $\left(5.84 \pm 0.06 \mathrm{~mA} / \mathrm{cm}^{2}\right)$, which is close to the theoretical value $\left(5.99 \mathrm{~mA} / \mathrm{cm}^{2}\right)$ obtained using kinematic viscosity $\left(1.009 \times 10^{-2} \mathrm{~cm}^{2} / \mathrm{s}^{59}\right)$, solubility $\left(1.26 \mathrm{~mol} / \mathrm{dm}^{359}\right)$ and diffusivity $\left.\left(1.90 \times 10^{-5} \mathrm{~cm}^{2} / \mathrm{s}^{60}\right)\right)$.

We fabricated catalysts layers using the two techniques discussed above for $\mathrm{PtCo} / \mathrm{C}$ as shown in Fig. 4 to verify the advantages of using the N-RAD technique. A similar enhancement ( $\mathrm{x}$ 1.6) in the measured SA between the N-RAD and N-SAD techniques was observed for $\mathrm{PtCo} / \mathrm{C}$ and $\mathrm{Pt} / \mathrm{HSC}$. The SA enhancement from $\mathrm{Pt} / \mathrm{HSC}$ to $\mathrm{PtCo} / \mathrm{HSC}$ observed for the films fabricated with both N-SAD and N-RAD techniques was almost identical (x1.9 and x2.0). Similar SA enhancement factors (x1.9) have been also reported in literature employing SAD technique for $\mathrm{PtCo} / \mathrm{C}{ }^{28}$

\section{Fig. 4}

Based on the experimental results for $\mathrm{Pt} / \mathrm{HSC}$ and $\mathrm{PtCo} / \mathrm{C}$ discussed above, we examined a series of PEMFC candidate catalysts tabulated in the experimental section exclusively using the N-RAD technique. Figure 5 depicts the ECA, SA and MA for Pt/HSC, PtCo/HSC, $\mathrm{PtNi} / \mathrm{HSC}$, PtCoMn/HSC (46 wt\% Pt). PtCo/HSC and PtNi/HSC exhibit x1.8-2.1 higher SAs although the MA was not significantly higher than Pt/HSC. The alloy catalysts show lower ECAs $\left(47-61 \mathrm{~m}^{2} / \mathrm{g}_{\mathrm{Pt}}\right)$ than Pt/HSC $\left(99 \pm 5 \mathrm{~m}^{2} / \mathrm{g}_{\mathrm{Pt}}\right)$ since the alloying procedure requires some heat treatment/annealing at high temperatures that leads to particle growth and agglomeration. PtCoMn/HSC exhibited the highest SA (x2.1 vs. Pt/HSC) and MA (x1.3). The SA increase observed for the PtCoMn/HSC is comparable to that reported in the literature for PtCoMn NSTF over Pt NSTF (x1.7) in $0.1 \mathrm{M} \mathrm{HClO}_{4}$ at $20^{\circ} \mathrm{C}^{61}$ A marginally higher SA enhancement observed for $\mathrm{PtCoMn} / \mathrm{HSC}$ could be due to contributions from the particle size effect. ${ }^{62}$ Although we have not observed a significant improvement in MA for the TKK Pt-alloy/C catalysts, some literature, as well as our work on $\mathrm{PtCo} / \mathrm{C}$ (not shown) from alternative suppliers have demonstrated $\sim 2-3$ times activity improvement. ${ }^{18,63-65}$ Part of the discrepancy may stem from different conditioning procedures, sensitivity to ionomer content, inconsistent baselines, etc.

Fig. 5 
The selection of $\mathrm{Pt} w \mathrm{t} \%$ has tremendous significance in the design of practical PEMFC electrodes since (i) the mean particle size increases with $\mathrm{Pt} w \mathrm{t} \%$, and (ii) the catalyst layer thickness decreases with $\mathrm{Pt} w \mathrm{t} \%$. In order to meet the end of life (EOL) durability and performance target, a compromise has to be made in the selection of the particle size; smaller Pt nanoparticles degrade more rapidly than larger particles but have a higher initial ECA and hence MA. Simultaneously, the catalyst layer thickness has to be optimized; a thick catalyst layer would lead to a higher catalyst layer resistance and $\mathrm{O}_{2}$ diffusion resistance whereas an extremely thin catalyst layer would tend to flood easily. Also, recent reports from automotive manufacturers suggest that catalysts with low ECAs can cause a negative impact at peak power density since the local mass transport resistance increases with the inverse of ECA. ${ }^{66-68}$ In Fig. 6, we observe that the $26 \mathrm{wt} \% \mathrm{Pt} / \mathrm{HSC}\left(142 \pm 2 \mathrm{~m}^{2} / \mathrm{g}_{\mathrm{Pt}}\right)$ has the highest ECA, but also the lowest $\mathrm{SA}$; as a result, the MA which is the product of the ECA and SA is not particularly high. For 67 $\mathrm{wt} \% \mathrm{Pt} / \mathrm{HSC}$, the ECA is low $\left(78.0 \pm 0.7 \mathrm{~m}^{2} / \mathrm{g}_{\mathrm{Pt}}\right)$ due to facile agglomeration of nanoparticles that are in close proximity during synthesis. For the three Pt/HSC catalysts evaluated in this study, $46.4 \mathrm{wt} \% \mathrm{Pt} / \mathrm{HSC}$ has a moderate ECA $\left(99 \pm 5 \mathrm{~m}^{2} / \mathrm{g}_{\mathrm{Pt}}\right)$ and the highest MA. With exception of $67 \mathrm{wt} \% \mathrm{Pt} / \mathrm{HSC}$, the $\mathrm{Pt} / \mathrm{HSC}$ and $\mathrm{Pt} / \mathrm{V}$ catalysts clearly exhibit a trend of lower SA with higher ECA that hints at the particle size effect.

\section{Fig. 6}

One of the issues that plague PEMFCs is the low durability of the high surface area carbon black supports. Carbon can start corroding at potentials as low as $0.2 \mathrm{~V}$ vs. SHE as per the Pourbaix diagrams but due to slow kinetics the corrosion currents become significant above $0.9 \mathrm{~V} .{ }^{69}$ Cathode catalysts are frequently exposed to such high potentials including OCV $(0.95 \mathrm{~V}$ when a thin membrane is used) as well as potentials $>1.5 \mathrm{~V}$ during start-up/shut-down and during fuel starvation at the anode. As a result, the carbon black support corrodes leading to agglomeration of Pt nanoparticles and a concomitant loss in ECA and MA. Although these issues have been addressed and partially mitigated through operational controls, a material solution would be preferable. Graphitized carbon supports (HSC: $\sim 800 \mathrm{~m}^{2} / \mathrm{g}$, G-HSC: $\sim 240 \mathrm{~m}^{2} / \mathrm{g}, \mathrm{V}$ : $\sim 240 \mathrm{~m}^{2} / \mathrm{g}, \mathrm{G}-\mathrm{V} \sim 80 \mathrm{~m}^{2} / \mathrm{g}$ ) are thus possible candidates for improving the durability of PEMFCs, but suffer from low surface areas and fewer sites for anchoring the Pt nanoparticles. Figure 7 clearly shows that the ECA for Pt nanoparticles on graphitized supports is lower than on high surface area HSC with a consequent lower MA for Pt/G-HSC as well as Pt/G-V. These catalysts might still be useful if at the end of cyclic durability tests, the Pt on graphitized supports exhibit higher activities due to their stability and corrosion-resistance as reported in literature. ${ }^{70-72}$ In Table 3, the ECA, SA and MA at $0.9 \mathrm{~V}$ vs. RHE in $0.1 \mathrm{M} \mathrm{HClO}_{4}$ for Pt based catalysts fabricated using the SAD and RAD techniques in this study as well as literature are summarized.

Fig. 7 
Table 3. Comparison of the ECA, SA and MA at $0.9 \mathrm{~V}$ vs. RHE in $0.1 \mathrm{M} \mathrm{HClO}_{4}$ for Pt based catalysts fabricated using the SAD and RAD techniques.

\begin{tabular}{|c|c|c|c|c|c|c|c|c|}
\hline $\begin{array}{l}\text { Metal Content } \\
{[w t \%]}\end{array}$ & Catalyst & Manufacture & $\begin{array}{c}\text { \# of } \\
\text { samples }\end{array}$ & $\begin{array}{l}\text { Fabrication } \\
\text { technique }\end{array}$ & $\begin{array}{c}\text { ECA } \\
{\left[\mathrm{m}^{2} / \mathrm{g}_{\mathrm{Pt}}\right]}\end{array}$ & $\begin{array}{l}\text { SA @ } 0.9 \mathrm{~V} \\
{\left[\mu \mathrm{A} / \mathrm{cm}^{2} \mathrm{Pt}\right]}\end{array}$ & $\begin{array}{l}\text { MA @ 0.9V } \\
{\left[\mathrm{mA} / \mathrm{mg}_{\mathrm{Pt}}\right]}\end{array}$ & Ref. \\
\hline $45.9 \mathrm{Pt}$ & $\mathrm{Pt} / \mathrm{HSC}$ & TKK & 2 & SAD & 80 & $305^{\mathrm{a}}$ & $242^{\mathrm{a}}$ & 18 \\
\hline $46 \mathrm{Pt}$ & $\mathrm{Pt} / \mathrm{HSC}$ & TKK & 10 & SAD & 91 & 292 & 266 & 28 \\
\hline $46.4 \mathrm{Pt}$ & $\mathrm{Pt} / \mathrm{HSC}$ & TKK & - & SAD & 79 & $360 \pm 70^{b}$ & $280^{b}$ & 30 \\
\hline $46.4 \mathrm{Pt}$ & $\mathrm{Pt} / \mathrm{HSC}$ & TKK & 28 & SAD & $98 \pm 6$ & $311 \pm 37$ & $303 \pm 33$ & 55 \\
\hline $46.4 \mathrm{Pt}$ & $\mathrm{Pt} / \mathrm{HSC}$ & TKK & 49 & RAD & $99 \pm 5$ & $485 \pm 50$ & $477 \pm 42$ & 55,56 \\
\hline 19.7 Pt & $\mathrm{Pt} / \mathrm{V}$ & E-TEK & 5 & RAD & $63 \pm 2$ & $746 \pm 26$ & $470 \pm 27$ & 31 \\
\hline 46.4 Pt & $\mathrm{Pt} / \mathrm{V}$ & TKK & 29 & RAD & $72 \pm 3$ & $670 \pm 25$ & $482 \pm 24$ & 55 \\
\hline $26.1 \mathrm{Pt}$ & $\mathrm{Pt} / \mathrm{HSC}$ & TKK & 4 & RAD & $142 \pm 2$ & $296 \pm 11$ & $419 \pm 18$ & This work \\
\hline $67 \mathrm{Pt}$ & $\mathrm{Pt} / \mathrm{HSC}$ & TKK & 4 & RAD & $78.0 \pm 0.7$ & $460 \pm 16$ & $359 \pm 13$ & This work \\
\hline $46 \mathrm{Pt}$ & $\mathrm{Pt} / \mathrm{G}-\mathrm{HSC}$ & TKK & 4 & RAD & $66 \pm 1$ & $550 \pm 20$ & $360 \pm 7$ & This work \\
\hline $29 \mathrm{Pt}$ & $\mathrm{Pt} / \mathrm{V}$ & TKK & 4 & RAD & $94.8 \pm 0.8$ & $486 \pm 42$ & $461 \pm 43$ & This work \\
\hline 46.2 Pt & $\mathrm{Pt} / \mathrm{G}-\mathrm{V}$ & TKK & 4 & RAD & $58.5 \pm 0.7$ & $803 \pm 24$ & $470 \pm 19$ & This work \\
\hline $\mathrm{Pt}: \mathrm{Co}=46: 5$ & PtCo/HSC & TKK & - & SAD & 56 & 555 & 309 & 28 \\
\hline $\mathrm{Pt}: \mathrm{Co}=46.4: 5.0$ & $\mathrm{PtCo} / \mathrm{HSC}$ & TKK & 24 & SAD & $47 \pm 2$ & $596 \pm 41$ & $280 \pm 12$ & This work \\
\hline $\mathrm{Pt}: \mathrm{Co}=46.4: 5.0$ & $\mathrm{PtCo} / \mathrm{HSC}$ & TKK & 4 & RAD & $51.0 \pm 0.9$ & $973 \pm 51$ & $495 \pm 22$ & This work \\
\hline $\mathrm{Pt}: \mathrm{Ni}=46.2: 6.0$ & $\mathrm{PtNi} / \mathrm{HSC}$ & TKK & 8 & RAD & $57 \pm 2$ & $882 \pm 60$ & $499 \pm 24$ & This work \\
\hline $\begin{array}{l}\text { Pt:Co:Mn = } \\
\text { 46.9:3.4:1.2 }\end{array}$ & $\mathrm{PtCoMn} / \mathrm{HSC}$ & TKK & 4 & RAD & $61 \pm 2$ & $1026 \pm 29$ & $630 \pm 28$ & This work \\
\hline
\end{tabular}

a: 1.15 times correction was applied for background subtraction based on the statement in Ref. 18, b: SA was extracted from Fig. 10 in Ref. 30, 1.12 times correction was applied to covert the extracted SA at $10 \mathrm{mV} / \mathrm{s}$ to that at $20 \mathrm{mV} / \mathrm{s}$ based on the statement in Ref. 30, and MA was calculated from the SA and ECA.

\section{Conclusions}

The use of arbitrary RDE measurement protocols and thick/non-uniform catalyst layers can lead to discrepancies in the reported values of the ORR activity of Pt-based catalysts. We applied standardized protocols and film fabrication procedures to evaluate a series of Pt-based electrocatalysts that are of significance to practical PEMFCs and compared them to wellestablished baselines values for Pt/HSC and Pt/V. Catalyst layers fabricated using the N-RAD technique produced films that were fairly uniform and exhibited reproducible ORR activity in $0.1 \mathrm{M} \mathrm{HClO}_{4}$ as compared to the conventional non-uniform films obtained using the N-SAD technique commonly reported in the literature. Future work includes evaluating the durability of these catalysts in RDE and down-selecting a few for MEA fabrication and testing in subscale PEM fuel cells.

\section{Acknowledgements}

Shyam S. Kocha gratefully acknowledges funding from the U.S. Department of Energy, Fuel Cells Technologies Program under Contract No. DE-AC36-08-GO28308 to the National Renewable Energy Laboratory. Kazuma Shinozaki's stay at NREL and CSM was funded by Toyota Central R\&D Labs., Inc. 


\section{References}

1. L. G. Austin and S. Almaula, J. Electrochem. Soc., 114, 927 (1967).

2. S. Srinivasan, H. D. Hurwitz, and J. O. Bockris, J. Chem. Phys., 46, 3108 (1967).

3. J. Giner and C. Hunter, J. Electrochem. Soc., 116, 1124 (1969).

4. J. Giner, J. M. Parry, S. Smith, and M. Turchan, J. Electrochem. Soc., 116, 1692 (1969).

5. K. F. Blurton, P. Greenberg, H. G. Oswin, and D. R. Rutt, J. Electrochem. Soc., 119, 559 (1972).

6. W. Vogel, J. Lundquist, and A. Bradford, Electrochim. Acta, 17, 1735 (1972).

7. J. Bett, J. Lundquist, E. Washington, and P. Stonehart, Electrochim. Acta, 18, 343 (1973).

8. H. R. Kunz and G. A. Gruver, J. Electrochem. Soc., 122, 1279 (1975).

9. L. J. Bregoli, Electrochim. Acta, 23, 489 (1978).

10. H. R. Kunz and G. A. Gruver, Electrochim. Acta, 23, 219 (1978).

11. M. Peuckert, T. Yoneda, R. A. Dalla Betta, and M. Boudart, J. Electrochem. Soc., 133, 944 (1986).

12. P. Björnbom, Electrochim. Acta, 32, 115 (1987).

13. T. Maoka, Electrochim. Acta, 33, 371 (1988).

14. Y. Takasu, N. Ohashi, X.-G. Zhang, Y. Murakami, H. Minagawa, S. Sato, and K. Yahikozawa, Electrochim. Acta, 41, 2595 (1996).

15. K. J. J. Mayrhofer, B. B. Blizanac, M. Arenz, V. R. Stamenkovic, P. N. Ross, and N. M. Markovic, J. Phys. Chem. B, 109, 14433 (2005).

16. H. Ye, J. A. Crooks, and R. M. Crooks, Langmuir, 23, 11901 (2007).

17. K. J. J. Mayrhofer, D. Strmcnik, B. B. Blizanac, V. Stamenkovic, M. Arenz, and N. M. Markovic, Electrochim. Acta, 53, 3181 (2008).

18. H. A. Gasteiger, S. S. Kocha, B. Sompalli, and F. T. Wagner, Appl. Catal. B Environ., 56, 9 (2005).

19. M. Nesselberger, S. Ashton, J. C. Meier, I. Katsounaros, K. J. J. Mayrhofer, and M. Arenz, J. Am. Chem. Soc., 133, 17428 (2011). 
20. K. C. Neyerlin, W. Gu, J. Jorne, A. Clark, and H. A. Gasteiger, J. Electrochem. Soc., 154, B279 (2007).

21. Y. Liu, M. W. Murphy, D. R. Baker, W. Gu, C. Ji, J. Jorne, and H. A. Gasteiger, J.

Electrochem. Soc., 156, B970 (2009).

22. Y. Liu, C. Ji, W. Gu, D. R. Baker, J. Jorne, and H. A. Gasteiger, J. Electrochem. Soc., 157, B1154 (2010).

23. Y. Liu, C. Ji, W. Gu, J. Jorne, and H. A. Gasteiger, J. Electrochem. Soc., 158, B614 (2011).

24. E. Antolini, L. Giorgi, A. Pozio, and E. Passalacqua, J. Power Sources, 77, 136-142 (1999).

25. Y.-X. Chen, M.-F. Li, L.-W. Liao, J. Xu, and S. Ye, Electrochem. commun., 11, 1434 (2009).

26. C. M. Zalitis, D. Kramer, and A. R. Kucernak, Phys. Chem. Chem. Phys., 15, 4329 (2013).

27. S. S. Kocha, J. W. Zack, S. M. Alia, K. C. Neyerlin, and B. S. Pivovar, ECS Trans., 50, 1475 (2012).

28. I. Takahashi and S. S. Kocha, J. Power Sources, 195, 6312 (2010).

29. Y. Garsany, I. L. Singer, and K. E. Swider-Lyons, J. Electroanal. Chem., 662, 396 (2011).

30. K. Ke, K. Hiroshima, Y. Kamitaka, T. Hatanaka, and Y. Morimoto, Electrochim. Acta, 72, 120 (2012).

31. Y. Garsany, J. Ge, J. St-Pierre, R. Rocheleau, and K. E. Swider-Lyons, J. Electrochem. Soc., 161, F628 (2014).

32. O. J. Curnick, B. G. Pollet, and P. M. Mendes, RSC Adv., 2, 8368 (2012).

33. K. Shinozaki, B. S. Pivovar, and S. S. Kocha, ECS Trans., 58, 15 (2013).

34. K. Kunimatsu, H. Hanawa, H. Uchida, and M. Watanabe, J. Electroanal. Chem., 632, 109 (2009).

35. J. Omura, H. Yano, M. Watanabe, and H. Uchida, Langmuir, 27, 6464 (2011).

36. J. Omura, H. Yano, D. A. Tryk, M. Watanabe, and H. Uchida, Langmuir, 30, 432 (2014).

37. M. Nesselberger, M. Roefzaad, R. F. Hamou, P. U. Biedermann, F. F. Schweinberger, S. Kunz, K. Schloegl, G. K. H. Wiberg, S. Ashton, U. Heiz, K. J. J. Mayrhofer, and M. Arenz, Nat. Mater., 12, 919 (2013).

38. A. R. Kucernak and E. Toyoda, Electrochem. commun., 10, 1728 (2008). 
39. H. Gerischer, I. Mattes, and R. Braun, J. Electroanal. Chem., 10, 553 (1965).

40. A. J. Bard and L. R. Faulkner, Electrochemical Methods: Fundamentals and Applications., 2nd ed., John Wiley \& Sons, New York, (2000), p. 833.

41. M. Itagaki, H. Hasegawa, K. Watanabe, and T. Hachiya, J. Electroanal. Chem., 557, 59 (2003).

42. N. Wakabayashi, M. Takeichi, H. Uchida, and M. Watanabe, J. Phys. Chem. B, 109, 5836 (2005).

43. N. Wakabayashi, M. Takeichi, M. Itagaki, H. Uchida, and M. Watanabe, J. Electroanal. Chem., 574, 339 (2005).

44. H. Yano, E. Higuchi, H. Uchida, and M. Watanabe, J. Phys. Chem. B, 110, 16544 (2006).

45. T. Toda, H. Igarashi, and M. Watanabe, J. Electroanal. Chem., 460, 258 (1999).

46. F. Gloaguen, F. Andolfatto, R. Durand, and P. Ozil, J. Appl. Electrochem., 24, 863 (1994).

47. T. J. Schmidt, H.A. Gasteiger, G. D. Stab, D. M. Kolb, and R. J. Behm, J. Electrochem. Soc., 145, 2354 (1998).

48. S. L. Gojković, S. K. Zecevic, and R. F. Savinell, J. Electrochem. Soc., 145, 3713 (1998).

49. U. A. Paulus, T. J. Schmidt, H. A. Gasteiger, and R. J. Behm, J. Electroanal. Chem., 495, 134 (2001).

50. Y. Garsany, O. A. Baturina, K. E. Swider-Lyons, and S. S. Kocha, Anal. Chem., 82, 6321 (2010).

51. B. G. Pollet and J. T. E. Goh, Electrochim. Acta, 128, 292 (2014).

52. D. van der Vliet, D. S. Strmcnik, C. Wang, V. R. Stamenkovic, N. M. Markovic, and M. T. M. Koper, J. Electroanal. Chem., 647, 29 (2010).

53. S. K. Zecevic, J. S. Wainright, M. H. Litt, S. L. Gojković, and R. F. Savinell, J. Electrochem. Soc., 144, 2973 (1997).

54. E. Higuchi, H. Uchida, and M. Watanabe, J. Electroanal. Chem., 583, 69 (2005).

55. K. Shinozaki, J. W. Zack, S. Pylypenko, B. S. Pivovar, and S. S. Kocha, J. Electrochem. Soc., submitted.

56. S. S. Kocha, DOE Annu. Merit Rev. Proc. Fuel Cells (2014)

http://www.hydrogen.energy.gov/pdfs/review14/fc111_kocha_2014_o.pdf. 
57. K. Shinozaki, J. W. Zack, R. M. Richards, B. S. Pivovar, and S. S. Kocha, J. Electrochem. Soc., 162, F1144 (2015).

58. T. Suzuki, S. Tsushima, and S. Hirai, Int. J. Hydrogen Energy, 36, 12361 (2011).

59. N. M. Markovic, H. A. Gasteiger, and P. N. Ross, J. Phys. Chem., 99, 3411 (1995).

60. K. E. Gubbins and R. D. Walker, J. Electrochem. Soc., 112, 469 (1965).

61. D. van der Vliet, C. Wang, M. Debe, R. Atanasoski, N. M. Markovic, and V. R. Stamenkovic, Electrochim. Acta, 56, 8695 (2011).

62. C. Wang, N. M. Markovic, and V. R. Stamenkovic, ACS Catal., 2, 891 (2012).

63. I. Spanos, J. J. K. Kirkensgaard, K. Mortensen, and M. Arenz, J. Power Sources, 245, 908 (2014).

64. Y. Huang, J. Zhang, A. Kongkanand, F. T. Wagner, J. C. M. Li, and J. Jorne, J. Electrochem. Soc., 161, F10 (2013).

65. C. Wang, M. Chi, D. Li, D. van der Vliet, G. Wang, Q. Lin, J. F. Mitchell, K. L. More, N. M. Markovic, and V. R. Stamenkovic, ACS Catal., 1, 1355 (2011).

66. A. Ohma, T. Mashio, K. Sato, H. Iden, Y. Ono, K. Sakai, K. Akizuki, S. Takaichi, and K. Shinohara, Electrochim. Acta, 56, 10832 (2011).

67. S. Jomori, N. Nonoyama, and T. Yoshida, J. Power Sources, 215, 18 (2012).

68. J. P. Owejan, J. E. Owejan, and W. Gu, J. Electrochem. Soc., 160, F824 (2013).

69. K. Kinoshita, Carbon: Electrochemical and Physicochemical Properties, 1st ed., WileyInterscience, New York, (1988), p. 560.

70. H. Yano, T. Akiyama, M. Watanabe, and H. Uchida, J. Electroanal. Chem., 688, 137 (2013).

71. H. Liu, J. Li, X. Xu, F. Wang, J. Liu, Z. Li, and J. Ji, Electrochim. Acta, 93, 25 (2013).

72. S. S. Kocha, in Polymer Electrolyte Fuel Cell Degradation, M. Mench, E. C. Kumbur, and T. N. Veziroglu, Editors, p. 89-214, Elsevier Inc. (2012). 


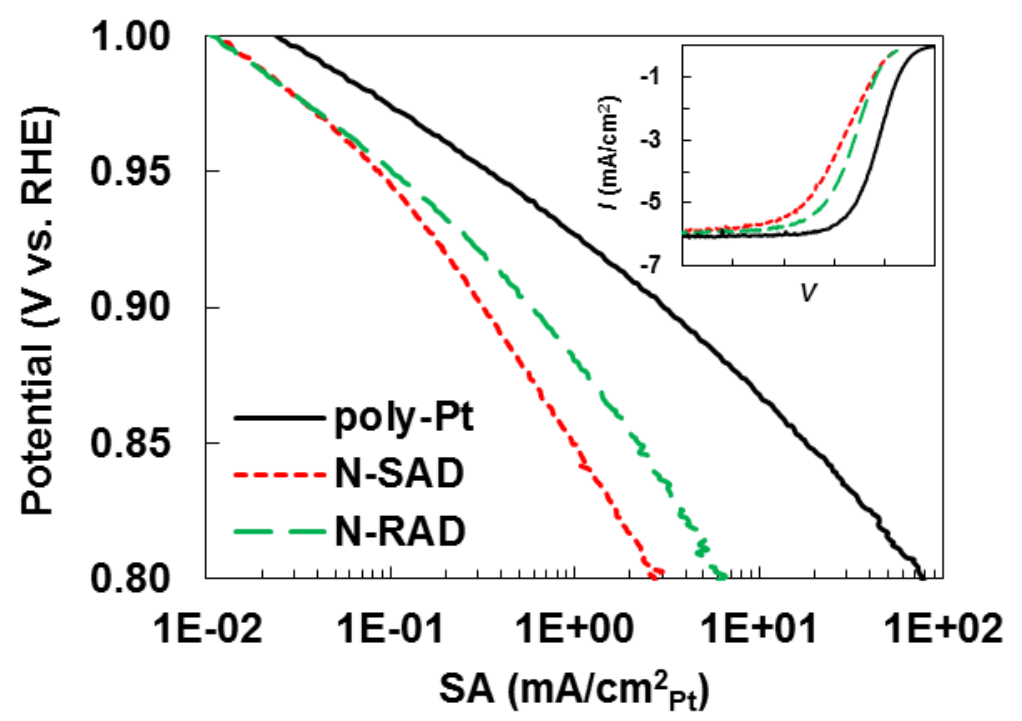

Fig. 1. (a) $I-V$ curves, and (b) Tafel plots for $46.4 \mathrm{wt} \% \mathrm{Pt} / \mathrm{HSC}$ catalyst layers fabricated using $\mathrm{N}-\mathrm{SAD}$ and N-RAD techniques. All experiments conducted at $23^{\circ} \mathrm{C}, 20 \mathrm{mV} / \mathrm{s}, 1600 \mathrm{rpm}$ in $\mathrm{O}_{2}$ saturated $0.1 \mathrm{M} \mathrm{HClO}_{4}$ electrolytes. 


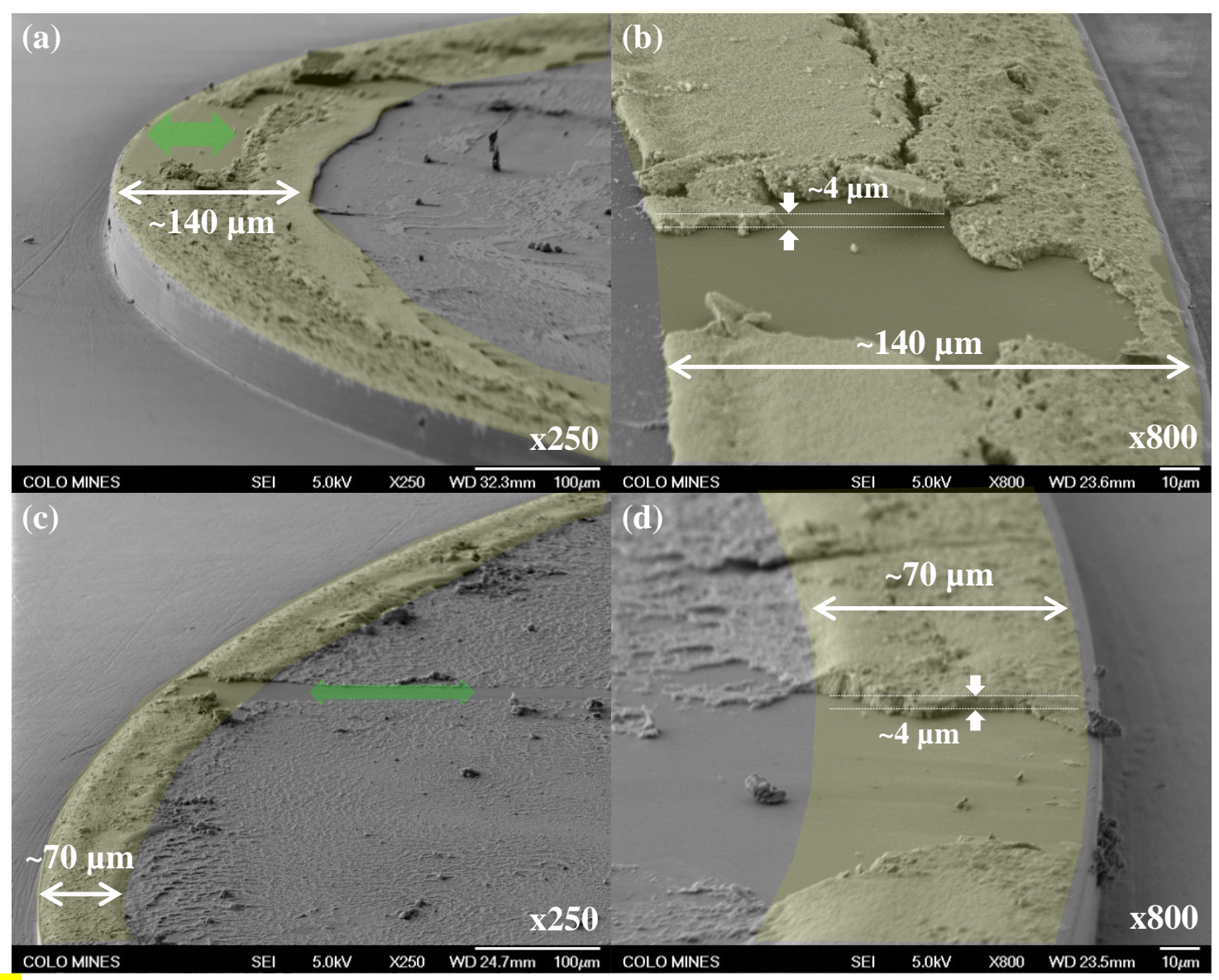

Fig. 2. Catalyst distribution estimation from tilted sample SEM images: (a, b) N-SAD, (c, d) NRAD, (a, c) near edge area, (b, d) edge area. Catalyst removed over a narrow band (green arrows) to facilitate observation and analysis of catalyst distribution in each local area. 


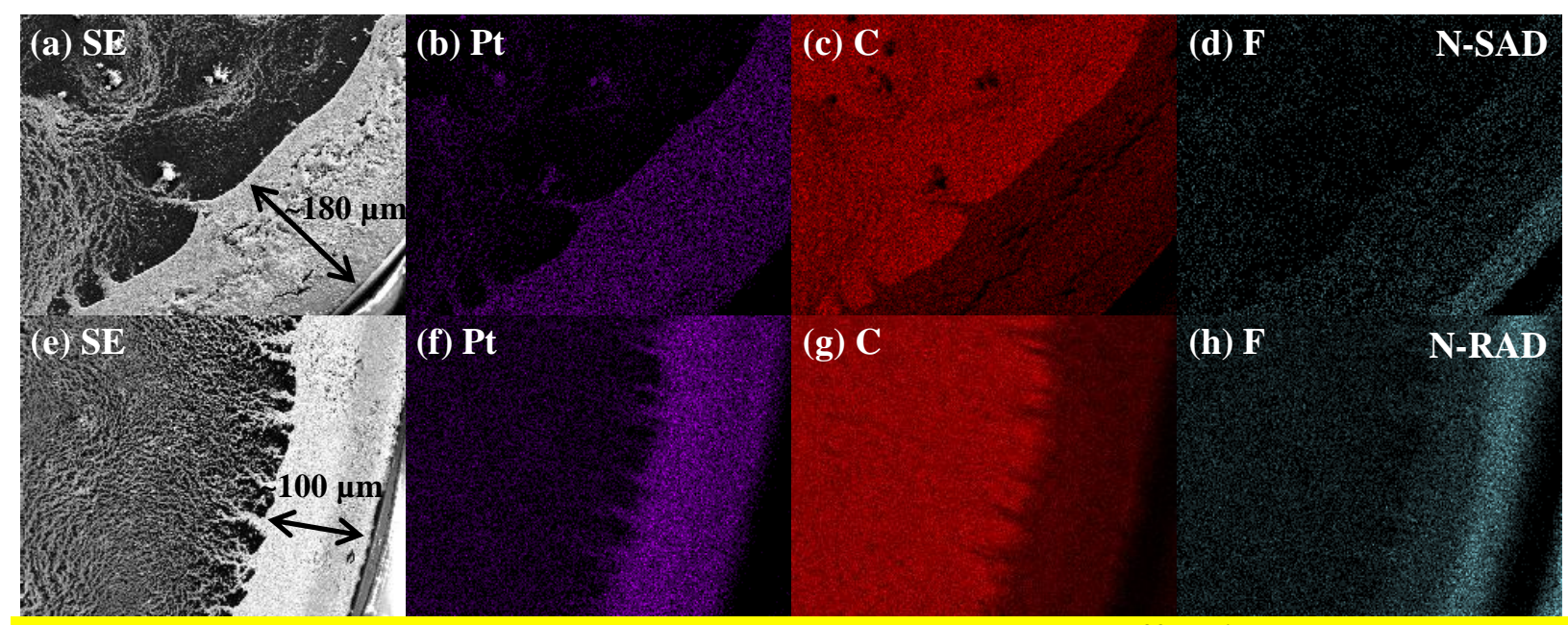

Fig. 3. SEM and EDX mapping images (x250) for the peripheral 'coffee ring' area of a Pt/HSC catalyst layers on GC substrate fabricated using the N-SAD (a-d) and RAD (e-h) techniques: (a, b) secondary electron $(\mathrm{SE}),(\mathrm{b}, \mathrm{f})$ platinum $(\mathrm{Pt})$ map, $(\mathrm{c}, \mathrm{g})$ carbon $(\mathrm{C})$ map, and $(\mathrm{d}, \mathrm{h})$ fluorine (F) map. 


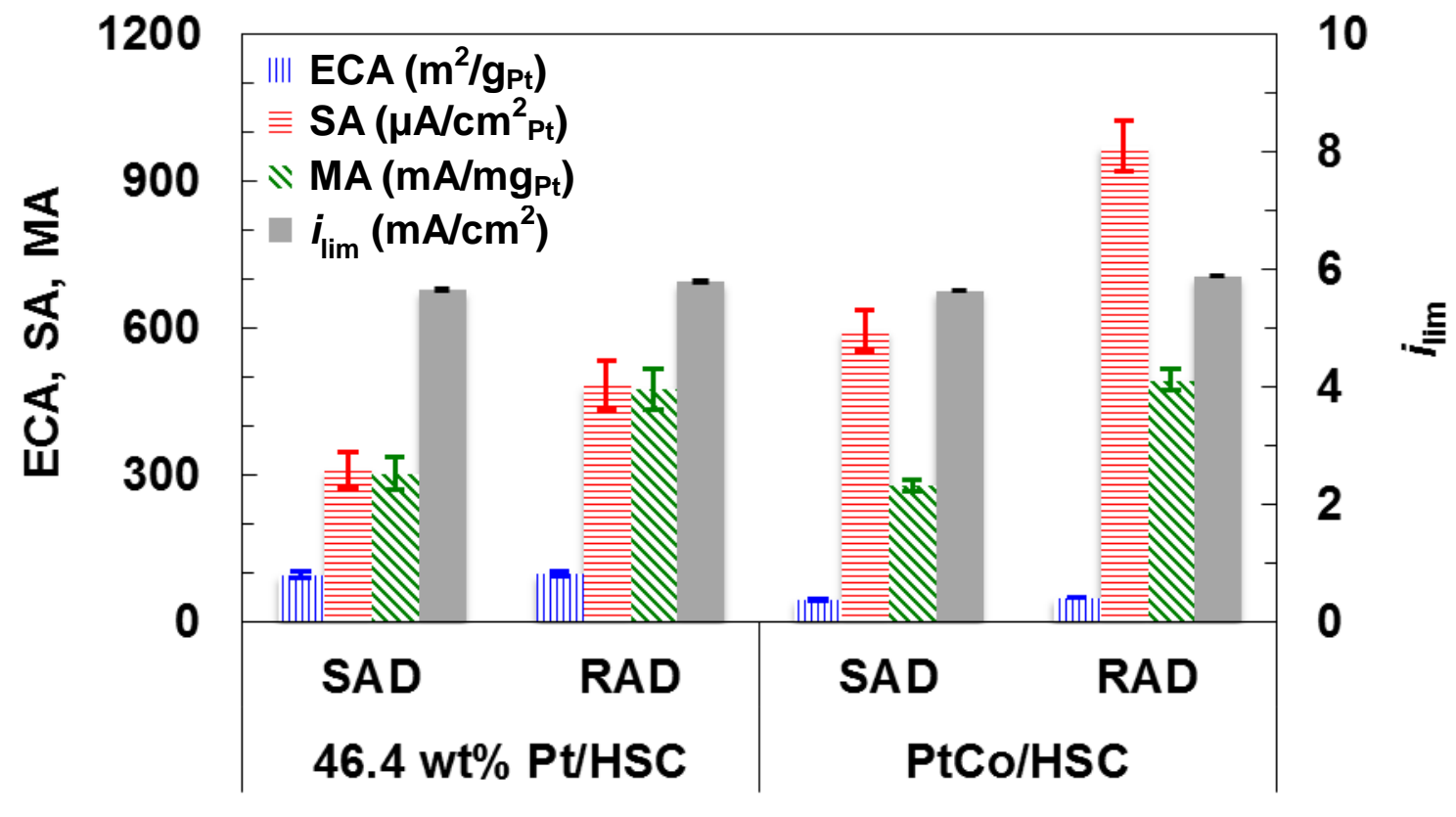

Fig. 4. ECA, SA and MA at $0.9 \mathrm{~V}$ vs. RHE for $46.4 \mathrm{wt} \% \mathrm{Pt} / \mathrm{HSC}$ and $\mathrm{PtCo} / \mathrm{HSC}$ catalyst layers fabricated using SAD and RAD techniques. All ORR experiments conducted at $23^{\circ} \mathrm{C}, 20 \mathrm{mV} / \mathrm{s}$, $1600 \mathrm{rpm}$ in $\mathrm{O}_{2}$ saturated $0.1 \mathrm{M} \mathrm{HClO}_{4}$ electrolytes. 


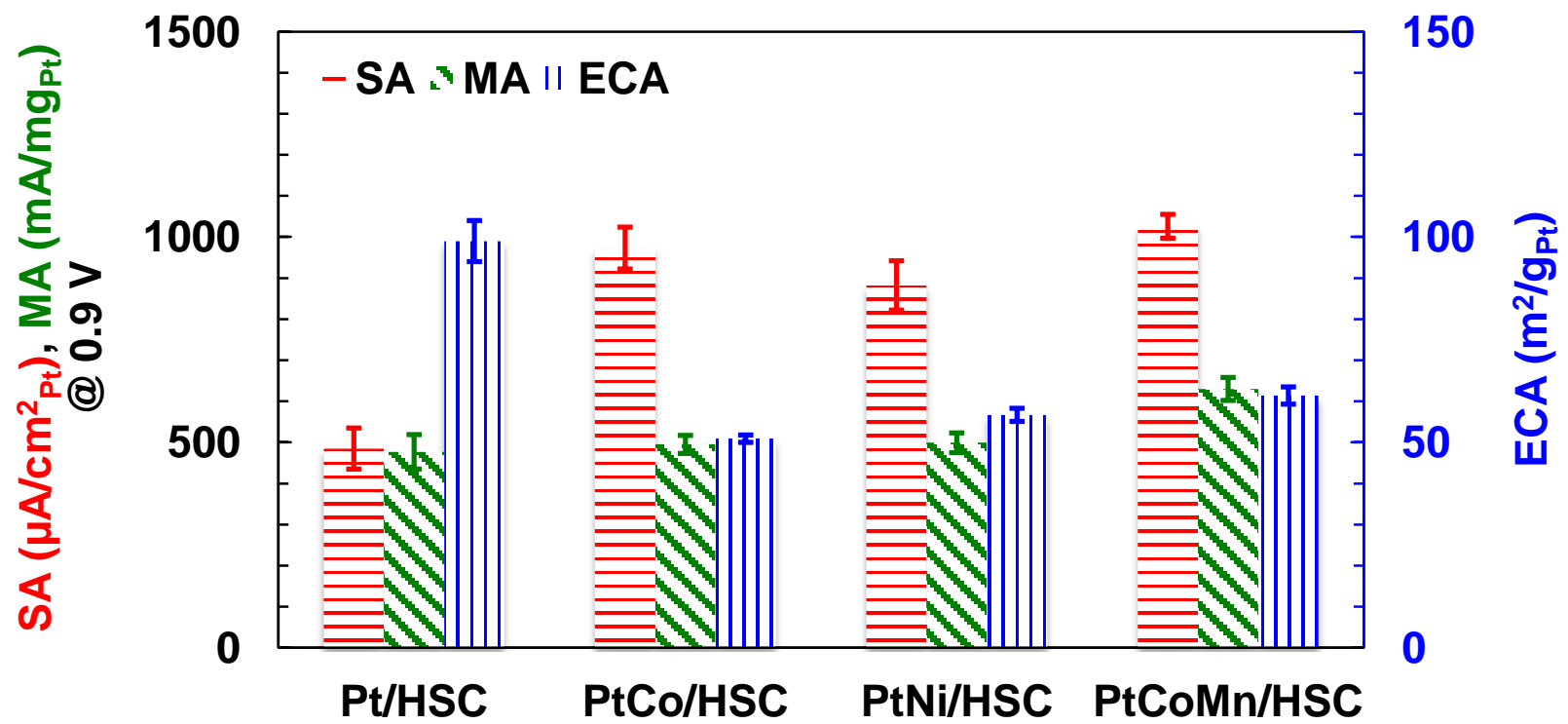

Fig. 5. ECA, SA and MA at $0.9 \mathrm{~V}$ vs. RHE for Pt/HSC and Pt-alloy/HSC (46 wt\% Pt) catalyst layers fabricated using RAD techniques. All ORR experiments conducted at $23^{\circ} \mathrm{C}, 20 \mathrm{mV} / \mathrm{s}$, $1600 \mathrm{rpm}$ in $\mathrm{O}_{2}$ saturated $0.1 \mathrm{M} \mathrm{HClO}_{4}$ electrolytes. 


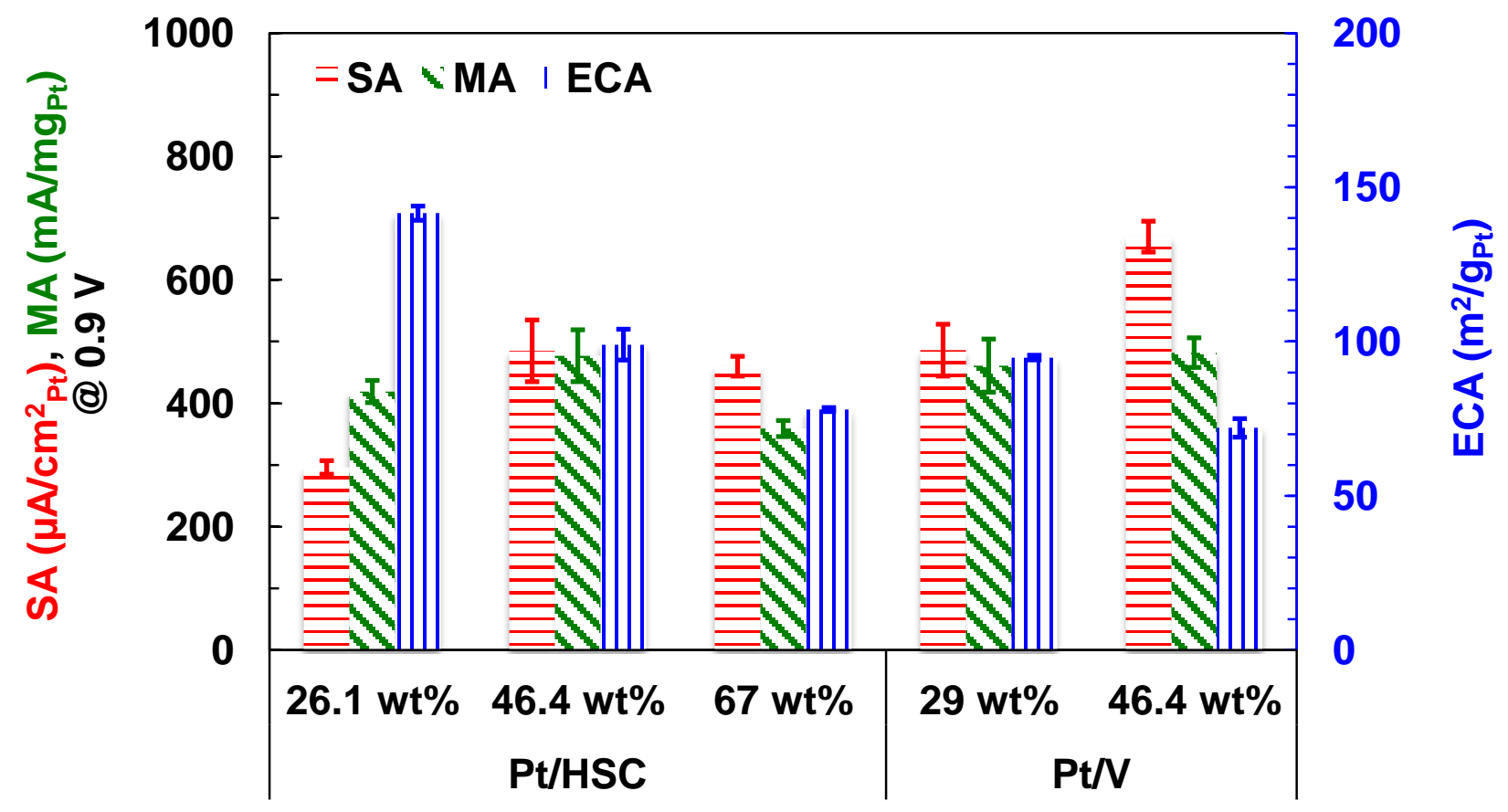

Fig. 6 ECA, SA and MA at $0.9 \mathrm{~V}$ vs. RHE for different Pt wt\% of Pt/HSC and Pt/V catalyst layers fabricated using N-RAD technique. All ORR experiments conducted at $23^{\circ} \mathrm{C}, 20 \mathrm{mV} / \mathrm{s}$, $1600 \mathrm{rpm}$ in $\mathrm{O}_{2}$ saturated $0.1 \mathrm{M} \mathrm{HClO}_{4}$ electrolytes. 


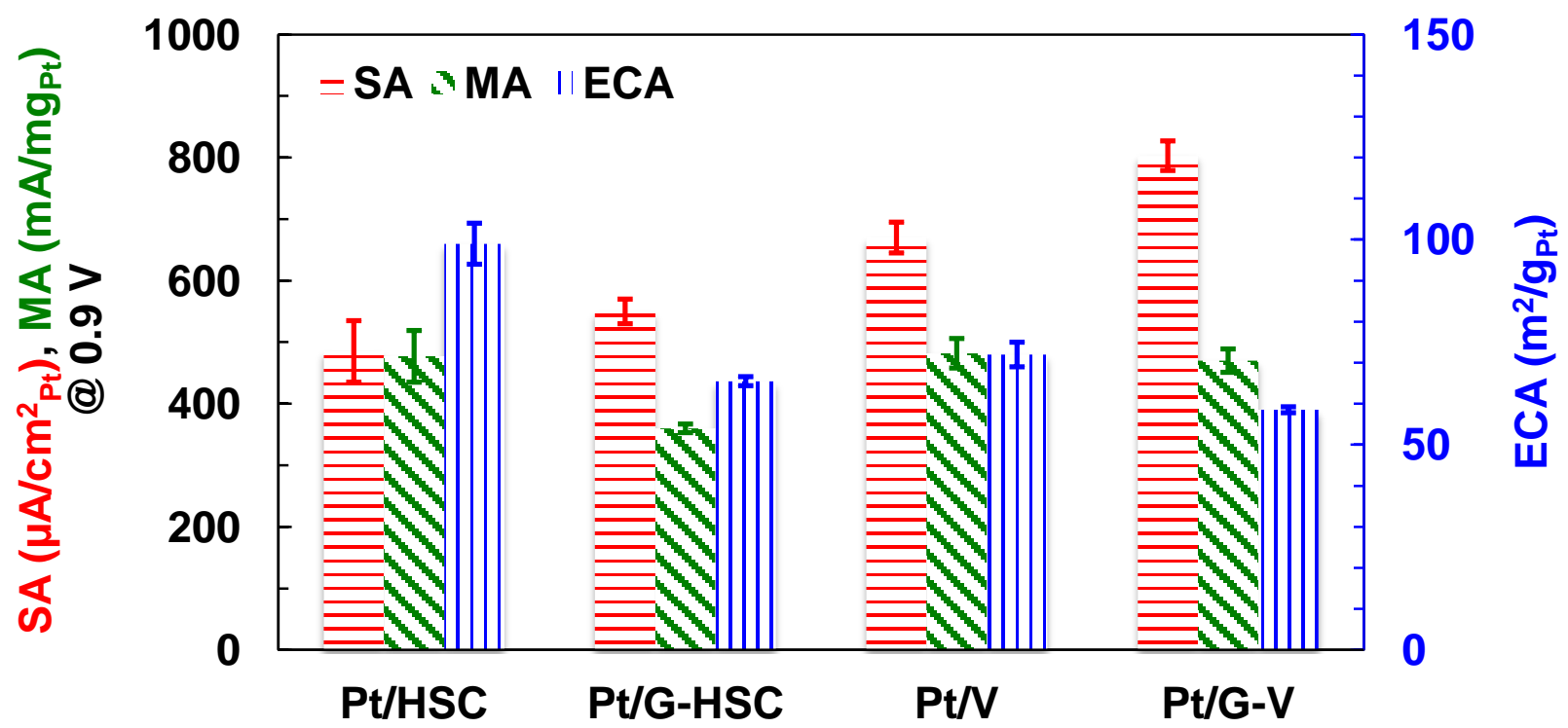

Fig. 7. ECA, SA and MA at $0.9 \mathrm{~V}$ vs. RHE for $46 \mathrm{wt} \%$ Pt supported on non-graphitized and graphitized carbons. Catalyst layers fabricated using N-RAD technique. All ORR experiments conducted at $23^{\circ} \mathrm{C}, 20 \mathrm{mV} / \mathrm{s}, 1600 \mathrm{rpm}$ in $\mathrm{O}_{2}$ saturated $0.1 \mathrm{M} \mathrm{HClO}_{4}$ electrolytes. 